\title{
Temporal Increase and Spatial Distribution of Sugarcane Yellow Leaf and Infestations of the Aphid Vector, Melanaphis sacchari
}

C. D. McAllister, former graduate student, J. W. Hoy, Department of Plant Pathology and Crop Physiology, and T. E. Reagan, Department of Entomology, Louisiana State University Agricultural Center, Baton Rouge 70803

\begin{abstract}
McAllister, C. D., Hoy, J. W., and Reagan, T. E. 2008. Temporal increase and spatial distribution of sugarcane yellow leaf and infestations of the aphid vector, Melanaphis sacchari. Plant Dis. 92:607-615.

Yellow leaf, caused by Sugarcane yellow leaf virus (ScYLV), is a potentially important disease of sugarcane first found in Louisiana during 1996. A survey during 2002 determined that ScYLV infection was present in all sugarcane-production areas of Louisiana. Virus was detected in $48 \%$ of 42 fields, and incidence averaged $15 \%$ in these fields. Disease progress curves determined in four fields during two growing seasons indicated that the greatest temporal increase of virus infection occurred during late spring and early summer and coincided with the initial infestation and increase of the virus vector, the sugarcane aphid (Melanaphis sacchari). Aphid infestations in the experimental fields during 2002 and 2003 ranged from 1.2 to 33.0 and 1.0 to 4.2 aphids per leaf, respectively. Final disease incidences of 2.9, 5.2, and 5.2\% were recorded in three fields planted with virus-free seed-cane. Distribution of ScYLV infections and aphids evaluated with spatial autocorrelation analysis indicated that ScYLV and its aphid vector both exhibited a predominantly random spatial distribution, with occasional aggregation. The low incidence and rates of disease increase observed, despite the widespread occurrence of potential vectors, suggest that inoculum pressure remains low in Louisiana. Therefore, it may be possible to keep yellow leaf at low levels by planting virus-free seed-cane.
\end{abstract}

Additional keyword: luteovirus

Yellow leaf, caused by Sugarcane yellow leaf virus (ScYLV), is a recently described disease of sugarcane (interspecific Saccharum hybrids) that has become important in some parts of the world (1$3,5,7,8)$. It was first detected in Hawaii in 1988 (14) and Brazil in 1992 (17). Yellow leaf was first detected in Louisiana in 1996 (9). In Louisiana, yield losses between 11 and $14 \%$ were recorded in $\mathrm{cv}$. LCP 82-89 (9).

In the tropics, the visible symptom of infection is a bright yellow midvein in young leaves at the apex of mature sugarcane stalks. The yellowing may spread to the leaf blade, and the upper surface of the midvein may turn reddish-pink (14). However, in Louisiana, symptoms are seldom observed because of the short growing season, frosts, and ripener applications.

ScYLV is a luteovirus that is efficiently transmitted by the sugarcane aphid, Melanaphis sacchari Zehntner, and less

Corresponding author: J. W. Hoy

E-mail: jhoy@agctr.lsu.edu

This manuscript has been approved by the Louisiana Agricultural Experiment Station as manuscript number 07-26-0181.

Accepted for publication 13 November 2007.

doi:10.1094/PDIS-92-4-0607

(C) 2008 The American Phytopathological Society efficiently by the corn leaf aphid, Rhopalosiphum maidis Fitch, and the rice root aphid, $R$. rufiabdominalis Sasaki $(13,16)$. Luteoviruses are limited to the phloem and are semipersistently transmitted by aphids. The sugarcane aphid was first discovered in Louisiana in 1999 (19). Each year, aphids fly into fields in Louisiana during seasonal movements. Trivial movement of insects then takes place within a breeding habitat. These trivial movements associated with colonization are interrupted when insects search for food or mates (18).

Sugarcane is a vegetatively propagated crop grown in a multiyear crop cycle with annual cuttings of stalks obtained from an initial planting. In Louisiana, a plant cane (first year) and two to three ratoon (regrowth) crops typically are obtained. Yellow leaf can be spread and increased by planting infected seed-cane and during infestation and colonization by viruliferous sugarcane aphids. Plant infection rates ranging from 20 to $95 \%$ have been recorded in plantings of virus-free seed-cane of susceptible cultivars within one to two growing seasons in Florida (6), Hawaii (15), and the island of Reunion (12).

The research objectives were to (i) determine the geographic distribution and incidence of ScYLV in Louisiana, (ii) determine the timing and rate of increase of ScYLV infection in fields of sugarcane, (iii) evaluate the association between aphid movements and colonization and ScYLV infection in the field, and (iv) determine the spatial distributions of aphid colonization and virus infections. The goals of the research were to gain information about the epidemiology of yellow leaf and apply that knowledge to the development of appropriate management strategies.

\section{MATERIALS AND METHODS}

Geographic distribution of yellow leaf. An initial survey of the sugarcaneproducing areas of Louisiana was conducted during July and August 2002 to determine the distribution of ScYLV throughout these areas and within fields. A second survey was conducted during June and July 2003 to determine whether the incidence of ScYLV infection had changed from one season to the next in fields selected from the previous survey. In 2002, 42 first ratoon (second annual harvested crop) fields of cv. LCP 85-384 randomly selected within different production areas were surveyed for ScYLV infection incidence (Table 1). LCP 85-384 was cultivated on $88 \%$ of the production area (193,000 ha total) during 2003 (10). In 2003, a subsample of 20 previously sampled fields was selected to assess the rate of increase from 2002 to 2003. A systematic sampling of leaves was conducted at each field in both years. Twenty-five rows from each field were sampled on a diagonal. Sampling was conducted beginning on the left-hand row. Twelve meters down the row, the youngest, fully emerged leaf was collected. Another $12 \mathrm{~m}$ along the same row, a second leaf was sampled. After collecting the second sample, the sampler crossed over the right-hand row and repeated the process until a total of 50 plants were sampled. All the leaf samples were cut to fit in 3.78-liter resealable plastic bags marked with field location and sample date. Each bag then was placed in an ice chest and taken to the laboratory for sample processing.

In the laboratory, leaf blades were removed manually, leaving only the midvein. A 4-cm section of midvein was cut with a scalpel. Scalpels were rinsed in distilled water, dipped in $70 \%$ ethanol for a minimum of $30 \mathrm{~s}$, and rinsed in water again before cutting the next midvein. An impression was made of each end of a midvein section (two imprints) onto a $0.45-\mu \mathrm{m}$ pore size nitrocellulose membrane (Schleicher and Schuell Bioscience, Dassell, Germany). 
Virus was detected using a tissue-blot enzyme-immunoassay procedure modified from Schenck (15). Blotted membranes were placed in plastic boxes, immersed in a $2 \%$ skim milk (Becton Dickinson and Company, Sparks, MD) phosphate buffered saline (PBS) solution for $1 \mathrm{~h}$, followed by one wash in PBS, pH 7.4, plus $0.05 \%$ Tween 20 (PBST). The membranes then were placed in a $1 \%$ skim milk solution containing a 1:4000 dilution of anti-SCYLV antibody and incubated in the refrigerator overnight at $4^{\circ} \mathrm{C}$. After three rinses with PBST, membranes were immersed in a solution of $1 \%$ skim milk with a 1:4000 dilution of goat-anti-rabbit immunoglobulin $\mathrm{G}$ antibody conjugated with alkaline phosphatase (Sigma-Aldrich, St. Louis) and placed on a rotary shaker for $1 \mathrm{~h}$. Mem-

Table 1. Louisiana sugarcane industry-wide survey for incidence of plants infected with Sugarcane yellow leaf virus in fields of first ratoon LCP 85-384 during 2002 and 2003

\begin{tabular}{|c|c|c|}
\hline \multirow[b]{2}{*}{ Location (Parish) } & \multicolumn{2}{|c|}{ Infection incidence $(\%)$} \\
\hline & 2002 & $2003^{a}$ \\
\hline Ascension & 0.0 & 0.0 \\
\hline Ascension & 0.0 & - \\
\hline Assumption & 0.0 & - \\
\hline Assumption & 0.0 & - \\
\hline Calcasieu & 0.0 & 0.0 \\
\hline Calcasieu & 2.1 & - \\
\hline Calcasieu & 20.4 & - \\
\hline Calcasieu & 2.0 & 0.0 \\
\hline Calcasieu & 2.0 & 0.0 \\
\hline Iberia & 0.0 & - \\
\hline Iberia & 0.0 & - \\
\hline Iberia & 0.0 & 0.0 \\
\hline Iberville & 44.9 & - \\
\hline Iberville & 8.2 & 8.0 \\
\hline Jefferson Davis & 24.0 & 26.5 \\
\hline Lafayette & 2.0 & - \\
\hline Lafourche & 0.0 & 0.0 \\
\hline Lafourche & 0.0 & - \\
\hline Lafourche & 62.7 & - \\
\hline Point Coupee & 10.0 & 6.3 \\
\hline Point Coupee & 0.0 & 0.0 \\
\hline Rapides & 0.0 & 0.0 \\
\hline Rapides & 0.0 & - \\
\hline Rapides & 0.0 & - \\
\hline Rapides & 0.0 & - \\
\hline Rapides & 26.0 & - \\
\hline St. James & 2.0 & 0.0 \\
\hline St. James & 2.0 & - \\
\hline St. James & 0.0 & - \\
\hline St. John & 10.0 & 12.0 \\
\hline St. Martin & 0.0 & - \\
\hline St. Martin & 2.0 & $5.9^{*}$ \\
\hline St. Mary & 2.1 & 2.0 \\
\hline St. Mary & 0.0 & 0.0 \\
\hline St. Mary & 0.0 & - \\
\hline Terrebonne & 3.9 & $8.2 *$ \\
\hline Vermilion & 0.0 & 0.0 \\
\hline Vermilion & 12.0 & 4.0 \\
\hline Vermilion & 41.2 & - \\
\hline West Baton Rouge & 14.0 & 24.0 \\
\hline West Baton Rouge & 0.0 & - \\
\hline West Baton Rouge & 0.0 & - \\
\hline
\end{tabular}

a Virus infection incidence values from 2003 followed by an asterisk $(*)$ were significantly different $(P=0.05)$ from the 2002 incidence value at the same site. $-=$ Field not sampled in 2003. branes were rinsed three times with PBST. The rinsed membranes were immersed in a substrate solution of Fast Blue BB hemi (zinc chloride) salt (Sigma-Aldrich) and magnesium chloride (anhydrous) (SigmaAldrich) and incubated in the dark on the shaker for $25 \mathrm{~min}$. Distilled, deionized water was used to rinse the membranes. The membranes then were immersed in a $20 \%$ bleach solution $(6 \%$ commercial sodium hypoclorite) for $15 \mathrm{~min}$, rinsed twice with water, and allowed to air dry overnight. Dried membranes were examined under a binocular microscope at $\times 20$. Positive virus detection results were indicated by blue to purple spots within phloem tubes in the vascular bundle imprints.

The percentage of virus-infected plants was calculated for each field. Infection incidence results that varied between years for a given field were statistically compared with a $t$ test.

Temporal increase of yellow leaf. The temporal increase of plants infected with ScYLV was monitored in four commercial sugarcane fields. Single plant cane (firstyear crop) fields in Iberville and Rapides Parishes (counties) were selected in November 2001 and monitored until August 2003 of the first ratoon crop. During 2001 and 2002, the plant cane field in Iberville Parish was monitored for virus infection incidence on 16 November 2001 and 3 April, 25 June, and 25 October 2002, and the plant cane field in Rapides Parish was monitored on 16 November 2001 and 4 April and 27 June 2002. During the 2003 first ratoon crop, data collection dates were 4 May, 17 June, and 21 August for the Iberville field and 3 May, 20 June, and 22 August for the Rapides field. Single second ratoon (third annual crop year) fields in Iberville and Iberia Parishes were selected in April 2002 and monitored through August 2003 and October 2003 of the third ratoon crop, respectively. During 2002, the second ratoon field in Iberville was monitored for virus incidence on 13 April and 25 June, and the Iberia field was monitored on 5 April and 25 June. During 2003, the Iberville field was monitored in third ratoon on 5 May, 18 June, and 21 August, and the Iberia field was monitored on 13 April, 19 June, and 3 October.

A section of each field, approximately $0.2 \mathrm{ha}$, along an edge or corner was selected for monitoring. Each field section was arranged as a 12-by-12 grid of 0.001ha $\left(3.6-\mathrm{m}^{2}\right)$ quadrats resulting in 144 contiguous quadrats. At each sampling date, four leaves (two leaves from each of the two plot rows) were sampled randomly from each quadrat. From each plant, the youngest fully emerged leaf was collected. Once all four leaves were collected, they were cut to fit into resealable plastic bags that were labeled with plot number and field location. Samples were taken to the laboratory and processed through the tissue-blot assay as previously described.
ScYLV infections persist in sugarcane plants over multiple growing seasons (12); therefore, recorded virus infections per quadrat could increase but not decrease in subsequent samplings. Sampling was begun in the two plant cane fields in late fall after the planted cane had emerged and in the two ratoon fields after cane had reemerged in the spring following the previous harvest. Sampling ceased during the late summer and fall of 2002 after the cane became lodged late in the growing season or during the following winter, when plants were not actively growing. Disease progress curves were plotted utilizing the cumulative percentages of ScYLV-infected plants out of 576 plants tested per field for sampling dates extending over two growing seasons.

Monitoring aphid infestations. $M$. sacchari infestations were monitored periodically from April through July or August during 2002 and 2003 in the same four fields. At the Iberville and Rapides plant cane fields in 2002, aphids were monitored on 19 April, 3 May, 12 June, 9 July, and 23 July in Iberville and 26 April, 8 May, 14 June, 10 July, and 2 August in Rapides. In 2003, when these two fields were in first ratoon, aphids were monitored on 4 May, 21 May, 4 June, 18 June, 7 July, and 23 July in Iberville and 3 May, 22 May, 6 June, 20 June, 7 July, 16 July, and 29 July in Rapides. At the Iberville and Iberia Parish second ratoon fields in 2002, aphids were monitored on 17 April, 4 May, 12 June, 9 July, and 23 July in Iberville and 24 April, 14 May, 12 June, 11 July, 23 July, and 8 August in Iberia. In 2003, when these fields were in third ratoon, aphids were monitored on 4 May, 22 May, 4 June, 18 June, 7 July, and 27 July in Iberville and 6 May, 22 May, 4 June, 19 June, 7 July, 16 July, and 29 July in Iberia. Infestations were monitored in each quadrat on the third or fourth leaf down from the whorl on four randomly selected plants (two on each of the two plot rows). Total numbers of both apterous and alate forms were recorded. Aphid count means and standard errors were computed for individual sampling dates using PROC MEANS (SAS Institute, Cary, NC).

Spatial distribution evaluation. Cumulative ScYLV infection and individual-date sugarcane aphid infestation quadrat data were analyzed for spatial autocorrelation using the Mantel Test (11) (SAS Institute). The data were analyzed using the 144 contiguous quadrats, then data were combined into larger contiguous quadrats so that the analyses were performed for dates extending over two seasons, with each field plot having 144 individual quadrats $\left(3.6 \mathrm{~m}^{2}\right), 36$ quadrats $\left(14.4 \mathrm{~m}^{2}\right), 16$ quadrats $\left(32.5 \mathrm{~m}^{2}\right)$, or 9 quadrats $\left(57.8 \mathrm{~m}^{2}\right)$.

\section{RESULTS}

Distribution of yellow leaf. The results of the survey conducted in 2002 indicated 
that plants were infected with ScYLV in commercial fields in all sugarcanegrowing areas of the state (20 parishes in southeast, south-central, and southwest Louisiana; Table 1). ScYLV was detected in 20 of the $42(48 \%)$ fields sampled in 2002. Incidence in fields with infected plants ranged from 2.0 to $62.7 \%$, with a mean of $14.6 \%$. Incidence in 2003 increased numerically in only five of nine resampled fields in which infected plants had been detected in 2002. A significant change in incidence was detected in only two fields, the St. Martin field that increased from 2.0 to $5.9 \%$ and the Terrebonne field that increased from 3.9 to $8.2 \%$. Infected plants were not detected in any of the 11 resampled fields with no infected plants in 2002.

Temporal increase of ScYLV infection incidence and sugarcane aphid infestations. Incidence of ScYLV infection increased from 0.4 to $2.9 \%$ in the field monitored in plant cane and first ratoon in Iberville Parish (Fig. 1). Disease incidence increased from $0.4 \%$ (1.4\% quadrats with infected plants) after the first sampling on 16 November 2001 to $0.9 \%$ (2.8\% quadrats with infected plants) on 3 April 2002. By 25 June, yellow leaf incidence increased to $1.7 \%$, with $5.6 \%$ of the quadrats infected. A further increase in infection incidence to $2.1 \%$ was detected in the 25 October sampling. Low numbers of aphids were detected from April to August 2002 (Fig. 1). Aphids were first detected on 3 May, when $1.4 \%$ of the plots were infested. The highest numbers of aphids per leaf (1.1) and highest percentage of plots $(11.1 \%)$ infested with aphids were detected on 12 June. Aphid numbers decreased during July. No increase of disease incidence was detected between the 25 October 2002 and 3 May 2003 samplings. In the first ratoon crop in 2003, yellow leaf incidence increased from $2.1 \%$ on 3 May (6.9\% quadrats with infected plants) to $2.8 \%$ on 20 June $(9.7 \%$ quadrats with infected plants) and at a lower rate to $2.9 \%$ on 22 August (10.4\% quadrats with infected plants). Aphids were detected on all sampling dates from May to July in 2003; however, the numbers per leaf were still low. As in 2002, aphid numbers per leaf and infested quadrats decreased at the end of July. As a percentage of aphid-infested quadrats, a maximum of 11 and $29 \%$ of the quadrats were infested by mid-June 2002 and 2003, respectively.

Incidence of yellow leaf increased from 0.5 to $5.2 \%$ over the two crop growing seasons (plant cane and first ratoon) in the Rapides Parish field (Fig. 2). Yellow leaf incidence increased between the 4 April and 27 June 2002 samplings from 1.0\% (4.2\% quadrats with infected plants) to $2.6 \%$ (9.7\% quadrats with infected plants). Low densities of aphids ( 0.01 per leaf) were first detected on 26 April $(0.7 \%$ infested plots), with no aphids detected on 8
May (Fig. 2). By 14 June, infestations averaged 2.4 aphids per leaf $(11.1 \%$ quadrats with infected plants). On 10 July, counts averaged 7.8 aphids per leaf $(65.3 \%$ quadrats with infected plants). By early August 2002, $72 \%$ of the quadrats were infested, averaging 2.6 aphids per leaf. During the first ratoon crop in 2003, virus incidence increased from $3.7 \%$ on 3 May
(13.9\% quadrats with infected plants) to $4.2 \% \quad(16.7 \%$ quadrats with infected plants) on 20 June, and to $5.2 \%$ (18.8\% quadrats with infected plants) on $22 \mathrm{Au}$ gust. Aphids infested $49 \%$ of the quadrats by 29 July, with a mean number of 2.4 aphids per leaf.

For the field monitored during second and third ratoon in Iberville Parish, virus

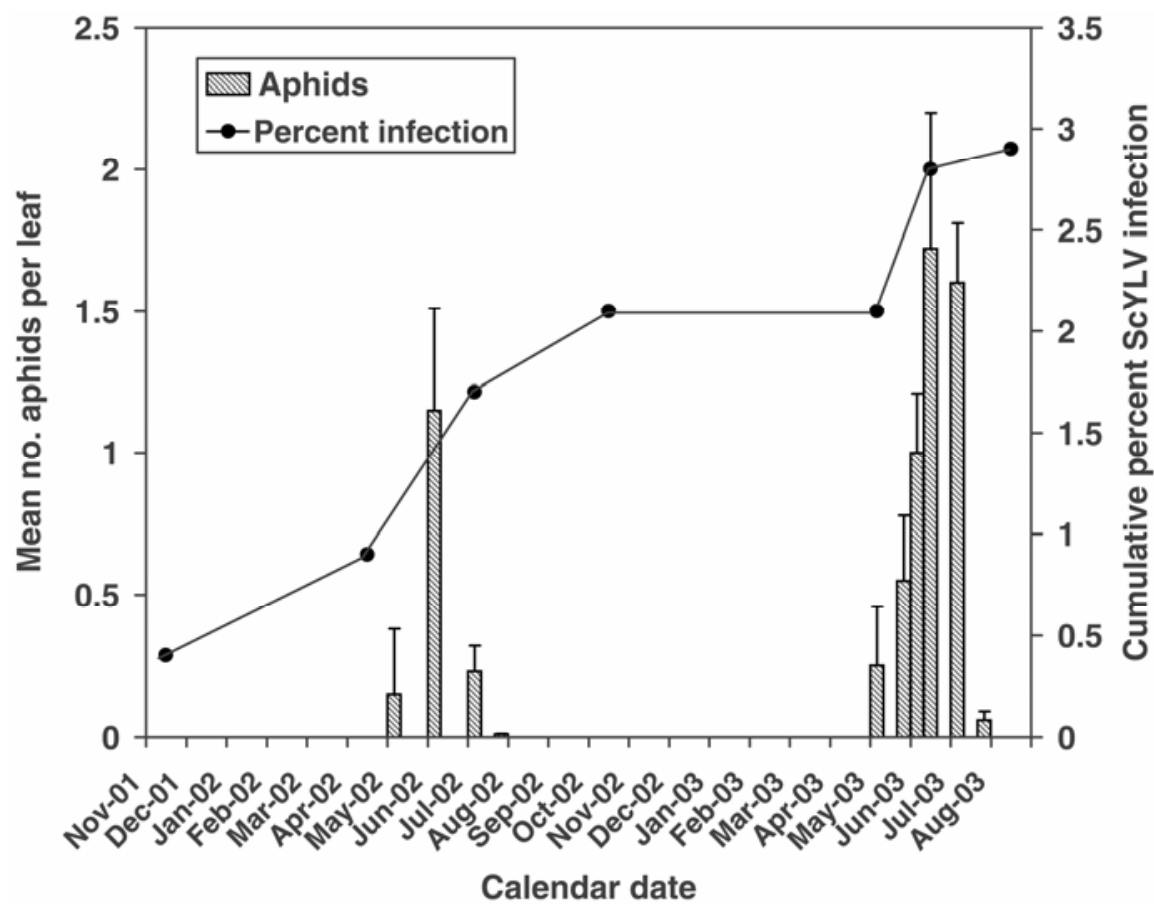

Fig. 1. Cumulative Sugarcane yellow leaf virus infection incidence and sugarcane aphid infestations at different sampling dates in an Iberville Parish sugarcane field during plant cane and first ratoon, 20012003.

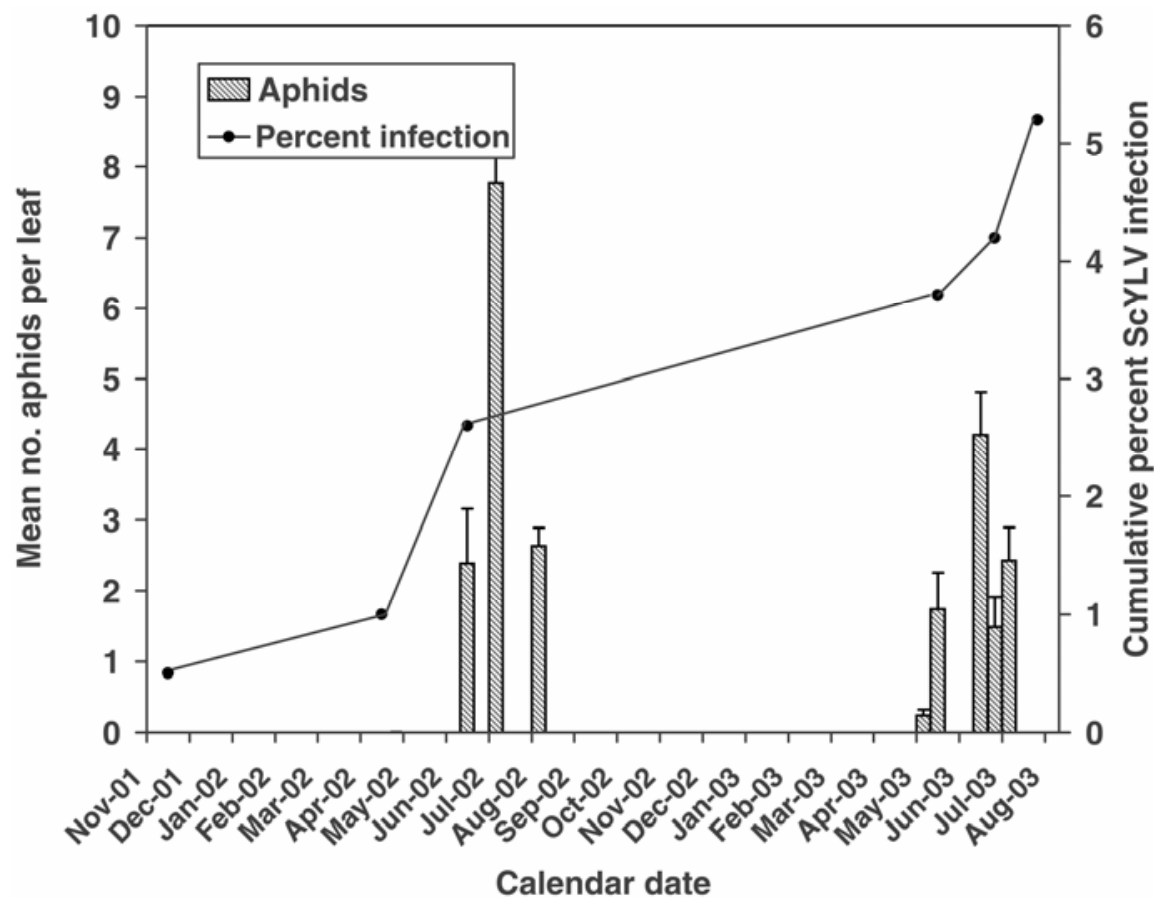

Fig. 2. Cumulative Sugarcane yellow leaf virus infection incidence and sugarcane aphid infestations at different sampling dates in a Rapides Parish sugarcane field during plant cane and first ratoon, 20012003. 
incidence increased from 12.2 to $25.9 \%$ over the study period (Fig. 3). Incidence of yellow leaf increased during every sampling period. During the second ratoon crop in 2002, yellow leaf increased from $12.2 \%$ (34.7\% infected quadrats) on 13 April to $17.0 \%$ (45.8\% infected quadrats) on 25 June. Aphids were first detected on 17 April, with one quadrat infested and a mean of less than one aphid per leaf (Fig. 3). By 12 June, 33 quadrats (22.9\%) were aphid infested, with a mean of 6.3 per leaf. By 23 July, only $5.8 \%$ of the quadrats were infested, with less than one aphid per leaf detected. When the third ratoon crop was sampled on 5 May 2003, yellow leaf incidence was $22.2 \%$ (59.0\% infected quadrats). Yellow leaf incidence was $25 \%$ $(65.3 \%$ infected quadrats) and $25.9 \%$ (67.4\% infected quadrats) by 18 June and 21 August 2003, respectively. Aphids were detected in one quadrat $(0.7 \%)$ on 4 May

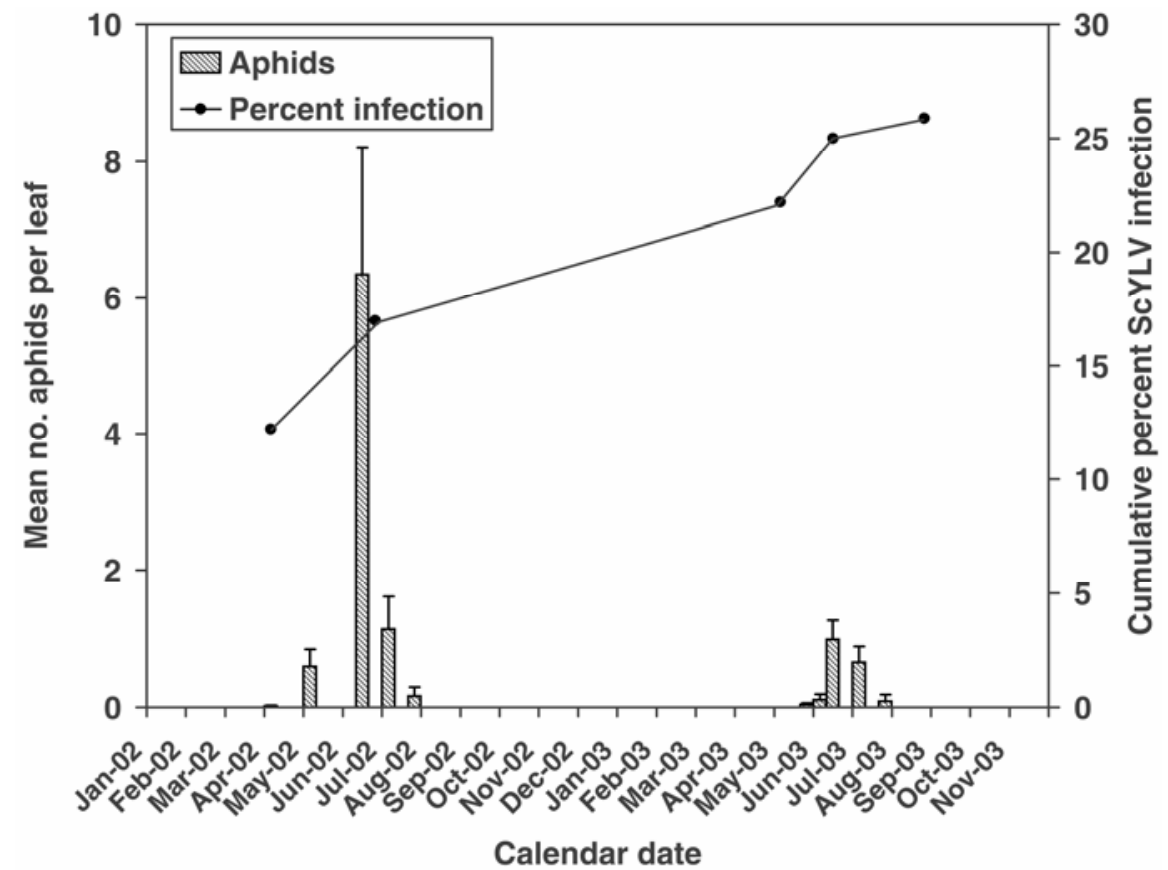

Fig. 3. Cumulative Sugarcane yellow leaf virus infection incidence and sugarcane aphid infestations at different sampling dates in an Iberville Parish sugarcane field during second and third ratoon, 20022003.

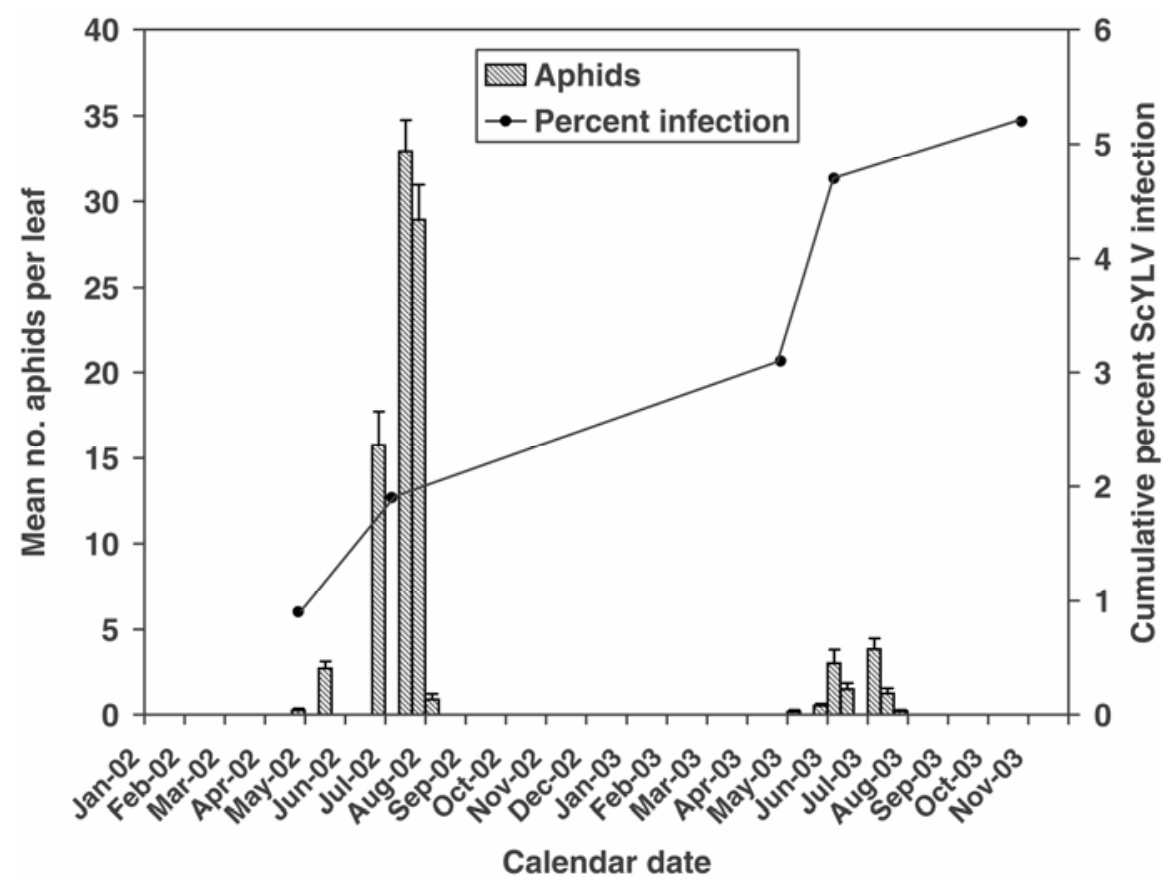

Fig. 4. Cumulative Sugarcane yellow leaf virus infection incidence and sugarcane aphid infestations at different sampling dates in an Iberia Parish sugarcane field during second and third ratoon, 20022003.
2003. On 18 June, a mean of 0.9 aphids was detected, with $12.5 \%$ of the quadrats infested. By 7 and 27 July, aphid infestations had declined to 9.7 and $0.7 \%$ of quadrats, respectively.

In the Iberia Parish field monitored in second and third ratoon, disease incidence increased from 0.9 to $5.2 \%$ (Fig. 4). Yellow leaf incidence during the second ratoon crop in 2002 began at $0.9 \%$ (3.5\% infected quadrats) on 5 April and subsequently increased to $1.9 \%$ (7.6\% infected quadrats) by 25 June. The spring movement of aphids was detected in May, with 64.6\% aphid-infested quadrats. The percentage of M. sacchari-infested quadrats peaked at $99 \%$ on 11 July, with an average of 33 aphids per leaf (Fig. 4). The numbers of aphids per leaf then decreased during August. During the third ratoon crop in 2003, yellow leaf incidence had increased to $3.1 \%$ (12.5\% infected quadrats) on 13 April, increasing to $4.7 \%$ (18.1 infected quadrats) by 19 June, then at a lower rate to $5.2 \%$ ( $20.1 \%$ infected quadrats) by 3 October. The spring movement of aphids was first detected on 6 May, with $4.2 \%$ of the quadrats aphid infested. By 22 May, $18.8 \%$ of the quadrats were aphid infested. With the influx of aphids, yellow leaf incidence also increased. Percentages of $M$. sacchari-infested quadrats on 4 June ( 3.0 aphids per leaf) were 30 and $44 \%$ on 7 July (3.8 aphids per leaf).

Spatial autocorrelation of ScYLV infection incidence. Analysis of ScYLV infection incidence using 144 quadrats showed no detectable autocorrelation on any of the sampling dates during plant cane or first ratoon in fields in Iberville Parish (Table 2) and Rapides Parish (Table 3 ), indicating that initial and subsequent infections were distributed randomly during two growing seasons. When quadrats were consolidated into larger (and fewer) contiguous grids, aggregation was not detected in the Iberville field with the 36-, 16-, and 9-quadrat grids (Table 2). For the Rapides field, aggregation was detected in the largest (nine-quadrat) grid for the last two sampling dates in 2002 and the initial sampling date during the first ratoon crop (Table 3). A field map of the 27 June 2002 results suggested a nonrandom, directional effect in the distribution of ScYLV infections (Fig. 5A). The analysis then indicated a return to a random distribution for the last two sampling dates in 2003. The random distribution during first ratoon is illustrated in the field plot map for 20 June 2003 (Fig. 5B).

At the second and third ratoon field in Iberville Parish, virus infection of plants initially was random in the 144 quadrat grid but then assumed an aggregated pattern on 25 June 2002 and 5 May 2003 (Table 4). However, the analyses showed a reversion to a random distribution for the last two sampling dates. No aggregation was detected at any larger quadrat size (Table 4). 
At the second and third ratoon field in Iberia Parish, the initial spatial pattern for ScYLV infections in the 144 quadrat grid was random (Table 5). The spatial pattern then alternated between aggregated and random for the next four sampling dates. The aggregation indicated by the analyses of the results with 144 quadrats was not detected with the larger quadrat sizes (Table 5).

Spatial autocorrelation of aphid infestations. Analyses of aphid infestations in the Iberville plant cane and first ratoon field using 144 quadrats detected no spatial autocorrelation, indicating a random dis- tribution of infested quadrats during all of 2002 (Table 2). Aphid distribution again was random in first ratoon except for the next to last monitoring date, 7 July 2003, when aggregation was detected (Table 2). Comparing 36 contiguous quadrats, the analysis detected spatial aggregation in the first ratoon crop on 18 June and 7 July 2003 (Table 2). Spatial aggregation was detected when comparing 16 quadrats on the first date aphids were detected, 3 May 2002 , then again, as in the 144- and 36quadrat analyses, at the 18 June and 7 July 2003 dates (Table 2). When the large ninequadrat grid was analyzed, aphids sampled on 7 July 2003 were aggregated similar to the other dates, whereas distribution at the remaining dates was random (Table 2).

In the Rapides Parish field, spatial autocorrelation analysis using 144 quadrats detected aggregation of aphid infestations at the last plant cane monitoring date, 2 August 2002 (Table 3). All other 2002 dates had a random spatial pattern. Aphid distribution was random at the beginning of the 2003 season, then became aggregated for the rest of the season, except for the 16 July sampling (Table 3). Analyses comparing larger quadrats indicated random distribution of aphids at all plant cane

Table 2. Spatial autocorrelation analysis using different quadrat sizes for an Iberville Parish field from 2001 to 2003 for Sugarcane yellow leaf virus (ScLYV) infection incidence and sugarcane aphid infestations

\begin{tabular}{|c|c|c|c|c|c|}
\hline \multirow[b]{2}{*}{ Date $^{\text {b }}$} & \multirow[b]{2}{*}{ Crop year ${ }^{c}$} & \multicolumn{4}{|c|}{ Spatial distribution of ScYLV infection and aphids ${ }^{a}$} \\
\hline & & 144 quadrats $\left(3.6 \mathrm{~m}^{2}\right)$ & 36 quadrats $\left(14.4 \mathrm{~m}^{2}\right)$ & 16 quadrats $\left(32.5 \mathrm{~m}^{2}\right)$ & 9 quadrats $\left(57.8 \mathrm{~m}^{2}\right)$ \\
\hline \multicolumn{6}{|l|}{ ScYLV } \\
\hline 16 November 2001 & 1 & Random & Random & Random & Random \\
\hline 3 April 2002 & 1 & Random & Random & Random & Random \\
\hline 25 June 2002 & 1 & Random & Random & Random & Random \\
\hline 25 October 2002 & 1 & Random & Random & Random & Random \\
\hline 4 May 2003 & 2 & Random & Random & Random & Random \\
\hline 17 June 2003 & 2 & Random & Random & Random & Random \\
\hline 21 August 2003 & 2 & Random & Random & Random & Random \\
\hline \multicolumn{6}{|l|}{ Aphids } \\
\hline 19 April 2002 & 1 & $\mathrm{nf}$ & $\mathrm{nf}$ & $\mathrm{nf}$ & $\mathrm{nf}$ \\
\hline 3 May 2002 & 1 & Random & Random & Aggregated* & Random \\
\hline 12 June 2002 & 1 & Random & Random & Random & Random \\
\hline 9 July 2002 & 1 & Random & Random & Random & Random \\
\hline 23 July 2002 & 1 & Random & Random & Random & Random \\
\hline 4 May 2003 & 2 & Random & Random & Random & Random \\
\hline 21 May 2003 & 2 & Random & Random & Random & Random \\
\hline 4 June 2003 & 2 & Random & Random & Random & Random \\
\hline 18 June 2003 & 2 & Random & Aggregated $*$ & Aggregated* & Random \\
\hline 7 July 2003 & 2 & Aggregated** & Aggregated $* * *$ & Aggregated $* * *$ & Aggregated $* * *$ \\
\hline 27 July 2003 & 2 & Random & Random & Random & Random \\
\hline
\end{tabular}

${ }^{\mathrm{a}} \mathrm{nf}=$ Aphids were not found during sampling and $*, * *$, and $* * *=$ probability level at $P<0.1,0.05$, and 0.01 , respectively.

${ }^{\mathrm{b}}$ Dates indicate ScYLV incidence sampling dates and aphid sampling dates over two crop years.

${ }^{\mathrm{c}}$ Crop year: $1=$ plant cane (first-year crop) and $2=$ first ratoon (second-year crop).

Table 3. Spatial autocorrelation analysis using different quadrat sizes for a Rapides Parish field from 2001 to 2003 for Sugarcane yellow leaf virus (ScYLV) infection incidence and sugarcane aphid infestations

\begin{tabular}{|c|c|c|c|c|c|}
\hline \multirow[b]{2}{*}{ Date $^{\text {b }}$} & \multirow[b]{2}{*}{ Crop year ${ }^{c}$} & \multicolumn{4}{|c|}{ Spatial distribution of ScYLV infection and aphids ${ }^{a}$} \\
\hline & & 144 quadrats $\left(3.6 \mathrm{~m}^{2}\right)$ & 36 quadrats $\left(14.4 \mathrm{~m}^{2}\right)$ & 16 quadrats $\left(32.5 \mathrm{~m}^{2}\right)$ & 9 quadrats $\left(57.8 \mathrm{~m}^{2}\right)$ \\
\hline \multicolumn{6}{|l|}{ ScYLV } \\
\hline 16 November 2001 & 1 & Random & Random & Random & Random \\
\hline 4 April 2002 & 1 & Random & Random & Random & Aggregated** \\
\hline 27 June 2002 & 1 & Random & Random & Random & Aggregated** \\
\hline 3 May 2003 & 2 & Random & Random & Random & Aggregated $* *$ \\
\hline 20 June 2003 & 2 & Random & Random & Random & Random \\
\hline 22 August 2003 & 2 & Random & Random & Random & Random \\
\hline \multicolumn{6}{|l|}{ Aphids } \\
\hline 26 April 2002 & 1 & Random & Random & Random & Random \\
\hline 8 May 2002 & 1 & $\mathrm{nf}$ & $\mathrm{nf}$ & $\mathrm{nf}$ & nf \\
\hline 14 June 2002 & 1 & Random & Random & Random & Aggregated $* *$ \\
\hline 10 July 2002 & 1 & Random & Random & Random & Random \\
\hline 2 August 2002 & 1 & Aggregated $* * *$ & Random & Random & Random \\
\hline 3 May 2003 & 2 & $\mathrm{nf}$ & $\mathrm{nf}$ & $\mathrm{nf}$ & $\mathrm{nf}$ \\
\hline 22 May 2003 & 2 & Random & Random & Random & Random \\
\hline 6 June 2003 & 2 & $\mathrm{nf}$ & $\mathrm{nf}$ & $\mathrm{nf}$ & nf \\
\hline 20 June 2003 & 2 & Aggregated $* * *$ & Aggregated $* * *$ & Aggregated $* * *$ & Aggregated** \\
\hline 7 July 2003 & 2 & Aggregated* & Aggregated* & Aggregated* & Random \\
\hline 16 July 2003 & 2 & Random & Random & Random & Random \\
\hline 29 July 2003 & 2 & Aggregated $* *$ & Aggregated $* *$ & Random & Random \\
\hline
\end{tabular}

${ }^{a}$ Asterisks *,**, and $* * *$ indicate probability levels at $P<0.1,0.05$, and 0.01 , respectively; $\mathrm{nf}=$ aphids were not found during sampling.

${ }^{\mathrm{b}}$ Dates indicate ScYLV incidence sampling dates and aphid sampling dates over two crop years.

${ }^{\text {b }}$ Crop year: $1=$ plant cane (first-year crop) and $2=$ first ratoon (second-year crop). 
dates except for the nine-quadrat grid on 14 June 2002 (Table 3). The larger quadrat analyses in first ratoon were similar to the 144 quadrat analysis, beginning with a random distribution and then becoming aggregated (Table 3 ). The 36-quadrat grid analysis was identical to the 144-quadrat analysis for the entire summer period, whereas aggregation of aphid infestation was not always detected at the larger scales. Maps of this field during both seasons provided examples of the spatial distribution and clustering of the aphid infestations. The map for 14 June 2002 suggests a nonrandom, directional aphid distribution in the first season (Fig. 5C) similar to that for ScYLV infections (Fig. 5A). A map for 20 June 2003 during first ratoon provides a contrasting example in which aphid distribution showed a clear directional effect (Fig. 5D) that is not matched by the random distribution of ScYLV infections (Fig. 5B) that had occurred over two seasons.

At the Iberville Parish second and third ratoon field, spatial autocorrelation analysis employing all quadrat sizes revealed that spatial aggregation of aphids occurred in second ratoon only on 17 April 2002 in the 16-quadrat grid (Table 4). During third ratoon, aggregation was indicated at the first date aphids were detected, 22 May, but only when 144 quadrats were compared. Aggregation was detected again on 7 July. Aggregation occurred at larger scales on single dates during June and July (Table 4).
During 2002, spatial autocorrelation analysis indicated slight aggregation of aphid infestations at the Iberia second ratoon field in the largest quadrat grid (Table 5). Aphid infestation levels increased rapidly, and aggregation was detected at multiple quadrat sizes on 11 and 23 July. Aphid distribution returned to a random pattern on the last monitoring date, 8 August, as aphid populations decreased. During third ratoon, aphid spatial distribution was random at all scales throughout the season, with the exception of 22 May for the nine-quadrat grid (Table 5).

\section{DISCUSSION}

The 2002 survey provided the first comprehensive evaluation of the distribution
A
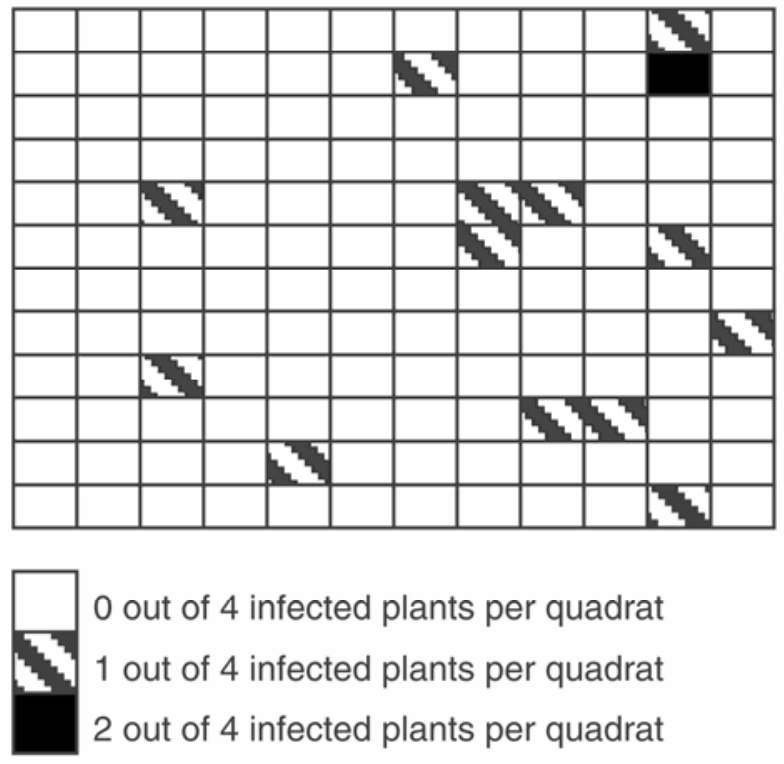

0 out of 4 infected plants per quadrat

1 out of 4 infected plants per quadrat

2 out of 4 infected plants per quadrat
C
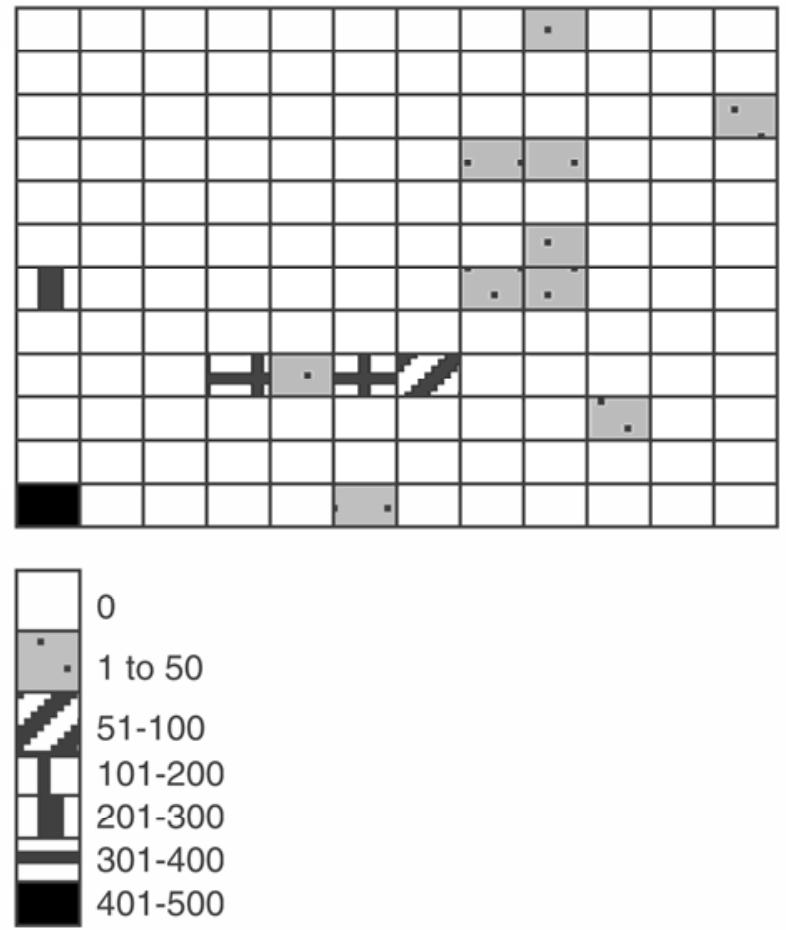

$\mathrm{D}$

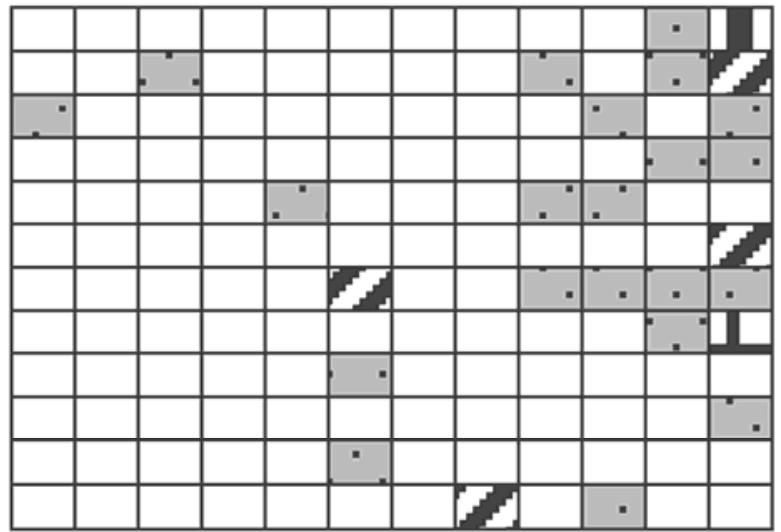

Fig. 5. Spatial distribution of virus infection and vector infestation in $1443.6-\mathrm{m}^{2}$ contiguous quadrats in a Rapides Parish sugarcane field in plant cane and first ratoon. A, Cumulative Sugarcane yellow leaf virus (ScYLV) infection incidence on 27 June 2002. B, Cumulative ScYLV infection incidence on 20 June 2003. C, Sugarcane aphid distribution on 14 June 2002. D, Sugarcane aphid distribution on 20 June 2003. 
and incidence of sugarcane yellow leaf since it was detected in Louisiana in 1996 (9). The results of the survey documented that ScYLV infections now occurred in all sugarcane-producing regions of Louisiana to varying degrees. Higher virus infection levels ranging from 20 to $63 \%$ were detected in six fields; however, these fields were not concentrated in any one production region. In over half of the fields surveyed, infection was not detected. The results of the survey in 2003 showed that only two of nine $(22 \%)$ fields had a significant incidence increase, and no infection was detected in any of the eight fields that were not infected in 2002. In addition, low levels of initial virus infection and increase were detected at the Iberville and Rapides Parish study sites, as well. These results suggest that, although yellow leaf has spread throughout Louisiana, rates of disease increase remain low.

Results from two seasons in four fields at three widely separated locations revealed that the period of most rapid increase of yellow leaf is associated with the spring movement of sugarcane aphids. Yellow leaf incidence continued to increase during the growing season, suggesting that secondary spread occurred at a lower rate as a result of aphid movement within fields or continued immigration. The only exception was the Rapides Parish site, where the rate of increase in incidence was greatest in the summer during first ratoon. The amount of disease spread during the summer between the first and second seasons could not be precisely determined because of the inability to sample during late summer or early fall after cane lodging had occurred. It is possible, perhaps even probable, given the documented decrease in aphid numbers during midsummer, that the increase in incidence detected the following spring occurred mostly during the summer months. The disease progress curve for the Iberville field in plant cane and first ratoon includes a data point obtained from sampling fall plant regrowth following an early harvest of the plant cane crop for seed-cane that supports

Table 4. Spatial autocorrelation analysis using different quadrat sizes for an Iberville Parish field from 2002 to 2003 for Sugarcane yellow leaf virus (ScLYV) infection incidence and sugarcane aphid infestations

\begin{tabular}{|c|c|c|c|c|c|}
\hline \multirow[b]{2}{*}{ Date $^{\mathbf{b}}$} & \multirow[b]{2}{*}{ Crop year ${ }^{c}$} & \multicolumn{4}{|c|}{ Spatial distribution of ScYLV infection and aphids ${ }^{a}$} \\
\hline & & 144 quadrats $\left(3.6 \mathrm{~m}^{2}\right)$ & 36 quadrats $\left(14.4 \mathrm{~m}^{2}\right)$ & 16 quadrats $\left(32.5 \mathrm{~m}^{2}\right)$ & 9 quadrats $\left(57.8 \mathrm{~m}^{2}\right)$ \\
\hline \multicolumn{6}{|l|}{ ScYLV } \\
\hline 13 April 2002 & 3 & Random & Random & Random & Random \\
\hline 25 June 2002 & 3 & Aggregated** & Random & Random & Random \\
\hline 5 May 2003 & 4 & Aggregated $* *$ & Random & Random & Random \\
\hline 18 June 2003 & 4 & Random & Random & Random & Random \\
\hline 21 August 2003 & 4 & Random & Random & Random & Random \\
\hline \multicolumn{6}{|l|}{ Aphids } \\
\hline 17 April 2002 & 3 & Random & Random & Aggregated*** & Random \\
\hline 3 May 2002 & 3 & Random & Random & Random & Random \\
\hline 12 June 2002 & 3 & Random & Random & Random & Random \\
\hline 9 July 2002 & 3 & Random & Random & Random & Random \\
\hline 23 July 2002 & 3 & Random & Random & Random & Random \\
\hline 4 May 2003 & 4 & $\mathrm{nf}$ & $\mathrm{nf}$ & $\mathrm{nf}$ & $\mathrm{nf}$ \\
\hline 22 May 2003 & 4 & Aggregated** & Random & Random & Random \\
\hline 4 June 2003 & 4 & Random & Random & Random & Random \\
\hline 18 June 2003 & 4 & Random & Random & Aggregated* & Aggregated* \\
\hline 7 July 2003 & 4 & Aggregated** & Aggregated* & Random & Aggregated* \\
\hline 27 July 2003 & 4 & Random & Random & Random & Random \\
\hline
\end{tabular}

a Asterisks *, **, and *** indicate probability levels at $P<0.1,0.05$, and 0.01 , respectively; $\mathrm{nf}=$ aphids were not found during sampling.

${ }^{b}$ Dates indicate ScYLV incidence sampling dates and aphid sampling dates over two crop years.

${ }^{\mathrm{c}}$ Crop year: 3 = second ratoon (third-year crop) and $4=$ third ratoon (fourth-year crop).

Table 5. Spatial autocorrelation analysis using different quadrat sizes for an Iberia Parish field from 2002-2003 for Sugarcane yellow leaf virus (ScLYV) infection incidence and sugarcane aphid infestations

\begin{tabular}{|c|c|c|c|c|c|}
\hline \multirow[b]{2}{*}{ Date $^{b}$} & \multirow[b]{2}{*}{ Crop year ${ }^{c}$} & \multicolumn{4}{|c|}{ Spatial distribution of ScYLV infection and aphids ${ }^{a}$} \\
\hline & & 144 quadrats $\left(3.6 \mathrm{~m}^{2}\right)$ & 36 quadrats $\left(14.4 \mathrm{~m}^{2}\right)$ & 16 quadrats $\left(32.5 \mathrm{~m}^{2}\right)$ & 9 quadrats $\left(57.8 \mathrm{~m}^{2}\right)$ \\
\hline \multicolumn{6}{|l|}{ ScYLV } \\
\hline 5 April 2002 & 2 & Random & Random & Random & Random \\
\hline 25 June 2002 & 2 & Aggregated* & Random & Random & Random \\
\hline 13 April 2003 & 3 & Random & Random & Random & Random \\
\hline 19 June 2003 & 3 & Aggregated* & Random & Random & Random \\
\hline 3 October 2003 & 3 & Random & Random & Random & Random \\
\hline \multicolumn{6}{|l|}{ Aphids } \\
\hline 24 April 2002 & 2 & Random & Random & Random & Aggregated* \\
\hline 14 May 2002 & 2 & Random & Random & Random & Random \\
\hline 12 June 2002 & 2 & Random & Random & Random & Random \\
\hline 11 July 2002 & 2 & Random & Aggregated** & Aggregated* & Aggregated* \\
\hline 23 July 2002 & 2 & Aggregated $* * *$ & Aggregated $* * *$ & Aggregated $* * *$ & Aggregated $* * *$ \\
\hline 8 August 2002 & 2 & Random & Random & Random & Random \\
\hline 6 May 2003 & 3 & Random & Random & Random & Random \\
\hline 22 May 2003 & 3 & Random & Random & Random & Aggregated** \\
\hline 4 June 2003 & 3 & Random & Random & Random & Random \\
\hline 19 June 2003 & 3 & Random & Random & Random & Random \\
\hline 7 July 2003 & 3 & Random & Random & Random & Random \\
\hline 16 July 2003 & 3 & Random & Random & Random & Random \\
\hline 29 July 2003 & 3 & Random & Random & Random & Random \\
\hline
\end{tabular}

a Asterisks *, **, and $* * *$ indicate probability levels at $P<0.1,0.05$, and 0.01 , respectively.

${ }^{\mathrm{b}}$ Dates indicate ScYLV incidence sampling dates and aphid sampling dates over two crop years.

${ }^{c}$ Crop year: 3 = second ratoon (third-year crop) and 4 = third ratoon (fourth-year crop). 
the contention that disease incidence does not increase during fall and winter.

The lowest infection levels occurred in the Iberville plant cane and first ratoon field, where only low numbers of aphids were found throughout the spring and summer samplings of both years. The temporal increase of yellow leaf exhibited a similar pattern in the Rapides and Iberia fields. Higher aphid infestation levels occurred in these fields but this did not result in a high rate of yellow leaf increase, suggesting that most of the aphids were nonviruliferous. The Rapides site was the northernmost location; therefore, migrating aphids would have passed through sugarcane-production areas in route to the field. Despite this, moderate to heavy aphid infestations resulted in only a 5\% infection incidence level after two seasons. At the Iberville second and third ratoon field, ScYLV infection incidence at the beginning of the experiment in April 2002 was $12.2 \%$; thus, the opportunity for secondary disease spread existed. The increase in incidence to $26 \%$ during the study suggests that some local spread (within the field) did occur. However, the greatest rate of disease increase in both seasons was associated with the annual movement of aphids during spring.

Currently, it appears that a majority of the migratory aphids are not viruliferous. This is in contrast to the situation in Florida and the island of Reunion. Natural infection rates detected in five sugarcane cultivars that were established from virusfree seed-cane resulted in virus infection levels ranging from 20 to $86 \%$ at the end of a 2-year experiment in Florida (6). ScYLV incidence was $42 \%$ in first ratoon of a susceptible cultivar planted with virusfree seed-cane in Reunion (12).

Several factors could have affected the outcome of spatial pattern analyses. Initial infection spatial patterns could be determined for the three fields that began with low ScYLV infection incidence and ended with 5\% incidence or less. Precise comparisons of aphid and virus infection distributions were not possible because the spatial pattern analyses for ScYLV were based on cumulative infection data, whereas the aphid analyses were conducted with individual-date data. The same leaves were not used for the determination of virus infection and aphid data. Leaves were collected from plants chosen randomly in each plot for virus infection and aphid sampling conducted on different dates. Apparently, many aphid infestations were ephemeral. Finally, the occurrence of many nonviruliferous aphids made it less likely that any clustering detected for aphids would exhibit close, consistently matching spatial orientation with ScYLV infections within a field. Despite these potential confounding factors, the spatial distribution results did reveal information about the epidemiology of yellow leaf.
The Iberville plant cane and first ratoon field had low aphid infestation. Aphid distribution was essentially random until mid-June during first ratoon, and no aggregation of ScYLV infection was detected. The lack of any edge effect or other clustering suggests that the viruliferous vectors were coming from areas removed from the study field. Aggregation of aphid infestations was detected at all four quadrat sizes during July in first ratoon. Evaluation of a map depicting the occurrence of aphid-infested quadrats indicated that infested plants were distributed on one side of the field; however, this pattern resulted from the disappearance of aphids from other parts of the field, not directional immigration. Aphids are subject to predation, but this was not monitored in this study. The reasons for the late-summer decreases of aphid populations are uncertain.

Higher levels of aphid infestation occurred in the Rapides field; however, incidence of ScYLV infection was randomly distributed except when the data for the nine largest quadrats $\left(57.8 \mathrm{~m}^{2}\right)$ were tested for spatial autocorrelation. Aggregation was detected at the largest scale of comparison for both aphid infestation and ScYLV infection, and examination of the field map suggested the occurrence of a similar edge effect for both variables. However, aggregation of aphid infestation in first ratoon did not result in aggregated virus infections. Considered altogether, the results again suggest that virus was introduced during aphid immigration, mostly from distant rather than nearby sources.

The distribution of ScLYV infection was random in the Iberia field. This field experienced high infestation with aphids in the first study season and moderate infestation in the second. Aggregation of aphids was detected during the first season; however, again, this was due to the disappearance of aphids in one portion of the quadrat grid. As in the first two study fields, the evidence suggests that local sources of inoculum were not important in the spread of ScYLV.

Yellow leaf was already present in the Iberville second ratoon field at the initiation of the experiment. Aphid infestations were distributed randomly in the first study season. Aggregation of ScYLV infection was detected at the second two sampling dates. This could have resulted from expansion of some previous seasons infections into small foci. Aphid infestation was low in the second season, but some aggregation occurred. However, the distribution of virus infection became random over time. These results suggest that secondary spread of the disease due to trivial movement of wingless aphids within the field is less important than immigration.

The reasons for the observed low rates of disease increase are uncertain. One factor could be the predominant cultivation of one cultivar. Resistance to yellow leaf is difficult to evaluate, and little is known about variability in this important trait. The study results suggest that LCP 85-384 may possess some degree of resistance to infection by ScYLV. Resistance to the sugarcane aphid is being evaluated, and results suggest that LCP 85-384 is not highly susceptible. Other possible factors affecting the aphid vector are the climatic conditions in Louisiana and the occurrence of predators and parasites.

At current incidence levels and with the observed rates of disease increase occurring, it may be possible to keep yellow leaf infection levels low in Louisiana by planting virus-free seed-cane. This disease management option is possible because two companies are already producing ScYLV-free commercial seed-cane through apical meristem culture. A certified seedcane program exists that is regulated by the Louisiana Department of Agriculture and Forestry. Leaf samples randomly collected during a mid-June inspection and tested for ScYLV infection should provide a reasonably accurate estimate of the incidence of yellow leaf in commercial seed-cane sources to be harvested during August and delivered for planting on farms. The results of this study suggest that it may be possible to successfully manage this recently introduced disease in the Louisiana sugarcane industry by continuously providing farmers with seed-cane that contains little or no ScYLV infection.

\section{ACKNOWLEDGMENTS}

We thank R. Gonsoulin of Ulysse Gonsoulin and Sons, Inc., New Iberia, LA, J. Gay of St. Louis Planting, Inc., Plaquemine, LA, and B. Allums of BNA Farms, Bunkie, LA for the use of their fields; L. Grelen and J. Paccamonti Research Associates, Louisiana State University (LSU) Agricultural Center Department of Plant Pathology and Crop Physiology for assistance in testing sugarcane leaves for virus; F. Posey (formerly LSU Agricultural Center Department of Entomology) and B. Viator, Calvin Viator Agricultural Consultants, LLC and R. Schmidt and J. Flanagan, County Agents for help in locating fields for the survey; and B. Bourgeois (former student research assistant LSU Department of Entomology), F. Reay-Jones, graduate research assistant, and W. Akbar, Research Associate, LSU Agricultural Center Department of Entomology, for field and technical assistance.

\section{LITERATURE CITED}

1. Alegría, O. M., Chatenet, M., Girard, J. C., Saldarriaga, S. A., and Nuget, A. 2000. First report of Sugarcane yellow leaf virus in Peru. Plant Dis. 84:1342.

2. Arocha, Y., Gonzalez, L., and Peralta, E. L. 1999. First report of virus and phytoplasma pathogens associated with yellow leaf syndrome of sugarcane in Cuba. Plant Dis. 83:1177.

3. Avila, M., Arrieta, C., Villalobos, W., and Lockhart, B. E. L. 2001. First report of Sugarcane yellow leaf virus (ScYLV) in Costa Rica. Plant Dis. 85:819.

4. Camann, M. A., Culbreath, A. K., Pickering, J., Todd, J. W., and Demski, J. W. 1995. Spatial and temporal patterns of spotted wilt epidemics in peanut. Plant Dis. 85:879-885.

5. Comstock, J. C., Irvine, J. E., and Miller, J. D. 
1994. Yellow leaf syndrome appears on the United States mainland. Sugar J. 3:33-35.

6. Comstock, J. C., and Miller, J. D. 2004. Yield comparisons: disease-free tissue cultures versus bud-propagated sugarcane plants and healthy versus yellow leaf infected plants. J. Am. Soc. Sugar Cane Technol. 24:31-40.

7. Comstock, J. C., Pena, M., Vega, J., Fors, A., and Lockhart, B. E. L. 2002. Report of Sugarcane yellow leaf virus in Ecuador, Guatemala, and Nicaragua. Plant Dis. 86:74.

8. Daugrois, J. H., Jean-Baptiste, I., Lockhart, B. E. L., Irey, M. S., Chatenet, M., and Rott, P. 1999. First report of Sugarcane yellow leaf virus in the French West Indies. Plant Dis. 83:588.

9. Grisham, M. P., Pan, Y. B., Legendre, B. L., Godshall, M. A., and Eggleston, G. 2001. Effect of sugarcane yellow leaf virus on sugarcane yield and juice quality. Proc. Int. Soc.
Sugar Cane Technol. 24:434-438.

10. Legendre, B. L., and Gravois, K. A. 2003. The 2003 sugarcane variety survey. Sugar Bull. 82(9):22-28.

11. Mantel, N. 1967. The detection of disease clustering and a generalized regression approach. Cancer Res. 27:209-220.

12. Rassaby, L., Girard, J.-C., Lemaire, O., Costet, L., Irey, M. S., Kodja, H., Lockhart, B. E. L., and Rott, P. 2004. Spread of Sugarcane yellow leaf virus in sugarcane plants and fields on the island of Reunion. Plant Pathol. 53:117-125.

13. Scagliusi, S. M., and Lockhart, B. E. L. 2000. Transmission, characterization, and serology of a luteovirus associated with yellowleaf syndrome of sugarcane. Phytopathology 90:120124.

14. Schenck, S. 1990. Yellow leaf syndrome-a new sugarcane disease. Page 38 in: Hawaiian Sugar Planters Assoc. Exp. Stn. Annu. Rep.
15. Schenck, S., Hu, J. S., and Lockhart, B. E. L. 1997. Use of a tissue blot immunoassay to determine the distribution of sugarcane yellowleaf virus in Hawaii. Sugar Cane 1997 (4):5-8.

16. Schenk, S., and Lehrer, A. T. 2000. Factors affecting the transmission and spread of Sugarcane yellow leaf virus. Plant Dis. 84:10851088.

17. Vega, J., Scagliusi, S. M. M., and Ulian, E. C. 1997. Sugarcane yellow leaf disease in Brazil Evidence of association with a luteovirus. Plant Dis. 81:21-26.

18. Wellington, W. G. 1964. Qualitative changes in populations in unstable environments. Can Entomol. 96:436-451.

19. White, W. H., Reagan, T. E., and Hall, D. G 2001. Melanaphis sacchari (Homoptera: Aphididae), a sugarcane pest new to Louisiana. Fla. Entomol. 84(3):435-436. 